\title{
Protein Fraction, Mineral Profile, and Chemical Compositions of Various Fiber-based Substrates Degraded by Pleurotus ostreatus
}

\author{
Brianda Susana Velázquez-De Lucio, ${ }^{\text {a,b }}$ Edna María Hernández-Domínguez, a Alejandro \\ Téllez-Jurado, ${ }^{\mathrm{a}}$ Maricela Ayala-Martínez, ${ }^{\mathrm{c}}$ Sergio Soto-Simental, ${ }^{\mathrm{c}}$ and Jorge Álvarez- \\ Cervantes $^{\mathrm{a}, *}$
}

\begin{abstract}
The objective of this study was to characterize the substrates after their degradation by $P$. ostreatus within 60 days of cultivation in four Mexican mushroom-producing companies, in order to use it as a complement feed for ruminants. The acid detergent fiber (ADF), neutral detergent fiber (NDF), protein fraction, and mineral profile were analyzed after degradation. Crude protein (CP) of companies 1 and 4 increased by $6.1 \%$ and $6.8 \%$, respectively $(p \leq 0.05)$. Soluble nitrogen reached $60 \%$ relative to un-degraded substrate with $43.8 \%$. Proteins A, B1, and B3 fractions increased compared to controls $(p \leq 0.05)$ at some companies. The B2 fraction was decreased in all the degraded substrates $(p \leq 0.05)$, but the $C$ fraction at companies 1,2 , and 3 presented no significant differences with respect to their controls $(p \leq 0.05)$. Crude fiber (CF), ADF, NDF, and hemicellulose $(\mathrm{HC})$ decreased while dry matter digestibility (DMD) increased to $55.5-58 \%$ on degrade substrates. The mineral composition increased disproportionately. The substrate degraded by $P$. ostreatus by improving its digestibility and soluble protein content may be a low-cost food supplement. However, due to its mineral imbalance, it is not recommended as the sole food source for ruminants.
\end{abstract}

Keywords: Protein fractions; Bromatological profiles; Microelements; Residues degraded; Fungi; Animal feed

Contact information: a: Universidad Politécnica de Pachuca UPP, Zempoala, Hidalgo, México b: Posgrado en Biotecnología, Universidad Politécnica de Pachuca UPP, Zempoala, Hidalgo, México; c: Instituto de Ciencias Agropecuarias, Universidad Autónoma del Estado de Hidalgo UAEH, Tulancingo, Hidalgo, México; *Corresponding author: jorge_ac85@upp.edu.mx

\section{INTRODUCTION}

Agricultural residues such as straw and husks have been used as feed for ruminants despite their high fiber content. However, the strong bonds between cellulose, hemicellulose, and lignin impede the microorganisms in the rumen from fully utilizing the carbohydrate content (cellulose and hemicellulose) (Van Kuijk et al. 2015). In principle, enhancing the digestion of these food sources can be achieved by delignifying the fiber content by physical and/or chemical means. Nonetheless, this involves two disadvantages, as it increases costs, and affects the environment. Biological processes using fungi such as Pleurotus ostreatus, in contrast, offer benefits: the production of fructiferous bodies apt for human consumption and, simultaneously, degraded materials with high enzyme and metabolite contents. The changes that substrates undergo after fungal growth, are due to the excretion of enzymes, radicals, and other chemical compounds that degrade the lignocellulose into polysaccharides. 
As the fructiferous body develops, the nitrogen in the lignocellulosic biomass is incorporated into the fungal protein to increase the nitrogen concentration (crude protein) and improve the nutritional quality of vegetable matter (Van Kuijk et al. 2015).

Mushroom production in the world has increased by $30 \%$ since 1978, exceeding $4.70 \mathrm{~kg}$ per capita annual consumption (Royse et al. 2017). China is the leading producer of edible mushrooms; on the other hand, Mexico is positioned as the largest producer in Latin America, generating around $80.8 \%$ of the total production in the region (RomeroArenas et al. 2015; Bellettini et al. 2019). In 2011, the production of fresh mushrooms in México reached 62,374 t, increasing every year, of which $4.76 \%$ corresponds to mushrooms (Pleurotus spp.), (Martínez-Carrera et al. 2016). The State of Hidalgo is Mexico's third-largest producer. Even though mushroom-growing is an important economic activity there, it is also a source of pollution, since the substrate generated by cultivation accumulates because it has no specific use. The modified composition of these substrates has drawn attention; however, they have been proposed as a food source for ruminants (Van Kuijk et al. 2015). Most research on biologically-degraded materials have focused on the fungus' effect on fiber (ADF, NDF, lignin) and digestibility. Few studies have set out to determine the composition of the nitrogenized compounds or the mineral profile of biologically-delignified material, despite their importance for animal health and formulating animal diets. Adequate supplies of mineral elements in feed supports the appropriate functioning of animal organisms, metabolic processes, and interactions between them, but inadequate administration in diets may result in deficiencies or excesses that can cause disease or even death (Calsamiglia et al. 2009; Spears and Weiss 2014).

The Cornell Net Carbohydrate and Protein System (CNCPS) has a sub-model that predicts rates of feedstuff degradation in the rumen, the passage of undegraded feed to the lower gut, and the amount of energy and protein that is available to the animal. In the CNCPS, structural carbohydrate (SC) and nonstructural carbohydrate (NSC) are estimated from sequential neutral detergent fiber analyses of the feed. Data from literature are used to predict fractional rates of SC and NSC degradation. Crude protein (CP) is partitioned into five fractions as a function of solubility in precipitating agents, buffer solutions, and detergent solutions (Sniffen et al. 1992). Fraction A represents the soluble protein considered as non-protein nitrogen (NNP), which is assumed to undergo degradation quickly into ammoniacal nitrogen in the rumen and, together with carbon skeletons and energy in the form of ATP, participates in the synthesis of microbial protein. Fraction B1 is a true soluble protein; B2 is a protein with intermediate degradation rates that partially degrades in the rumen and small intestine; and B3 is considered an escape or bypass protein since it degrades very slowly in the rumen due to its bonding to the cell wall so it can go through the small intestine, where it is used by the animal. Finally, fraction $\mathrm{C}$ is an unavailable protein because it bonds to lignin (Lanzas et al. 2008; Van Soest 2018; Nayan et al. 2018).

In light of the foregoing, the high generation of residues degraded by P. ostreatus, and the biological advantages they offer, make them ideal candidates for use as animal feed; however, characterizations of the protein fractions and mineral content of these residues are scarce. Therefore, the main objective of this study was to characterize the various fiber substrates degraded by $P$. ostreatus, for 60 days of cultivation, at four mushroom-producing companies in Hidalgo, Mexico, in order to assess their possible use as a supplement in ruminant feedings. 


\section{EXPERIMENTAL}

\section{Obtaining the Vegetable Matter}

A sample of the fiber-based substrate was obtained prior to cultivation as a control sample. Six samples of degraded substrates were taken after 60 days of cultivation with $P$. ostreatus in various locations of Tolcayuca $\left(19^{\circ} 57^{\prime} 24^{\prime \prime} \mathrm{N}, 98^{\circ} 55^{\prime} 13^{\prime \prime} \mathrm{W}\right)$ (Company 1 ),

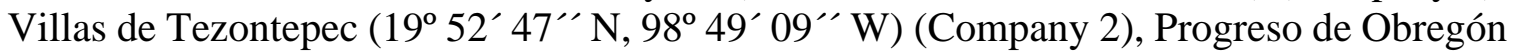
$\left(20^{\circ} 14^{\prime} 53^{\prime \prime} \mathrm{N}, 99^{\circ} 11^{\prime} 23^{\prime \prime} \mathrm{W}\right)$ (Company 3), and Cuautepec de Hinojosa $\left(20^{\circ} 09^{\prime} 00^{\prime \prime}\right.$ $\mathrm{N}, 98^{\circ} 26^{\prime} 00^{\prime \prime} \mathrm{W}$ ) (Company 4), in Hidalgo. The companies used substrates that contain barley straw, corn chaff-barley straw (50:50), corn chaff-oat straw (50:50), and corn chaff, respectively. The companies, as listed, use different strains of $P$. ostreatus: (Company 1: BPR-3 strain; Company 2: PR5 strain; Company 3: L85 C11 strain; Company 4: Pleutorus spp. Strain).

\section{Physicochemical Characterization}

Bromatological analyses were performed following the methodologies proposed by the AOAC (AOAC 2005) to determine moisture (M) (925.10), crude protein (CP) (960.52), ethereal extract (EE) (945.16), crude fiber (CF) (962.09), and ash (923.03). Acid detergent fiber (ADF) and neutral detergent fiber (NDF) were determined using the methodology of Van Soest et al. (1991). Hemicellulose (HC) was calculated from the difference between NDF and ADF. Protein fractions (A, B1, B2, B3, C) were performed following the method of Krishnamoorthy et al. (1982), while mineral composition was obtained from atomic absorption spectrometry (AOAC 2005).

\section{Dry Matter Digestibility}

The digestibility percentage of the dry matter (\% DMD) was calculated using Eq.1 (Linn and Martin 1991; Boga et al. 2014).

$$
\operatorname{DMD}(\%)=88.9-0.779 *(\mathrm{ADF})
$$

\section{Statistical Analyses}

The data obtained in triplicate had a completely random arrangement. Each independent variable was subjected to a normality analysis using the Shapiro-Wilk test in the PAST computer program, version 3.21 (Hammer 2018), and a variance analysis (ANOVA) with $\mathrm{P}<0.05$. To examine the differences between controls and the degraded substrates for all the analyzed parameters, a Student-t test was performed with $\mathrm{P}<0.05$. The comparison between the means of the companies was analyzed by applying a Tukey test for multiple ranges with $\mathrm{P}<0.05$, using Minitab 18.

\section{RESULTS AND DISCUSSION}

The industry dedicated to the production of edible mushrooms generates as a byproduct a high amount of degraded substrate worldwide, which is little used and is often discarded, burned or accumulated, generating serious pollution problems. During colonization and growth, fungi improve the nutritional value of the residues, increasing the content of vitamins, protein, and digestibility (Villas-Bôas et al. 2002); however, in order 
for these substrates to be incorporated into the ruminant diet, it must be ensured that they have an increase in crude protein and digestibility.

There are several studies on the chemical characterization of post-cultivation degraded substrates of fungi, which show that the strain, type of substrate used, cultivation technology, and geographical area, are some of the factors that influence the nutritional quality and digestibility of degraded substrates (Ruiloba et al. 2014). Variations due to these factors have limited their use. A lack of a standardized production process, as wells as the handling of different substrates and strains, gives rise to differences in chemical composition in degraded substrates. Therefore, it is necessary to carry out research for each region and in this way to establish whether or not they are candidates as supplements for ruminants.

In this sense, this research found that the comparative analysis of the chemical composition of the residue without degrading and those obtained after 60 days of cultivation, showed statistically significant changes $(\mathrm{P} \leq 0.05)$ in material from all the companies under study, with an increase in $\mathrm{CP}, \mathrm{EE}$, ash, DMD, soluble protein and decrease in $\mathrm{CF}, \mathrm{ADF}, \mathrm{NDF}, \mathrm{HC}$, and insoluble protein (Table 1 and 2). Proteins A, B1, and B3 fractions increased compared to controls $(\mathrm{p} \leq 0.05)$ at some companies (Table 3 and 4$)$. Company 4 presented the best bromatological analysis results, followed by companies 3 , 2 , and 1 . These improvements can be attributed to the type of strain used, which was the most efficient in degrading different fiber fractions that are present in corn straw, reflecting in a significant decrease in NDF that corresponds to the fibers of the cell wall (lignin, cellulose and hemicellulose), ADF, and HC. The content of ethereal extract increased in all degraded residues relative to its controls. There have been no reports that explain this behavior, possibly due to the production of fatty acids during the growth of the mycelium and fruiting bodies of the fungus.

These results confirm that when using substrates rich in lignin such as oat and barley straw, biodegradation is limited and the strain plays an important role in the ability to produce enzymes that allow it to degrade lignin. This makes it possible to access the sugars present in hemicellulose and cellulose in order to take advantage of them as energy sources during the colonization of the substrate and its subsequent fruiting (Anike et al. 2016). Pleurotus ostreatus is a white rot fungus identified as a species capable of improving the nutritional conditions of lignocellulosic materials because of its high selectivity for degrading lignin (Van Kuijk et al. 2015).

On the other hand, the proportion of ash in the degraded substrates in comparison with their controls increased significantly $(\mathrm{P} \leq 0.05)$ (Tables 1 and 2$)$. It has been mentioned that this increase is due to the addition of calcium sulfate and calcium carbonate to the substrates during the cultivation of the fungi; therefore, increases the ash content in the degraded residues, generating an imbalance in the minerals and limiting its use as ruminant feed (Urrego et al. 2013; Pineda-Insuasti et al. 2014; Zhang et al. 2014). Adamović et al. (1998) found higher ash content in substrate degraded by P. ostreatus over wheat straw after 30 days. Ruiloba et al. (2014), who reported similar behavior for ash in substrate of rice straw degraded by strains RN82 and RN81 of Pleurotus djamor. Increased ash concentration is frequently reported on fungal degraded substrates and indicates the presence of organic matter degradation (Assi and King 2008; Koutrotsios et al. 2014; Atila 2017, Nasehi et al. 2017; Wanzenböck et al. 2017).

For mineral composition analysis, the degraded substrates from company 1, which had the lowest ash content was selected. The percentages of the macro-minerals $\mathrm{P}, \mathrm{Ca}, \mathrm{Mg}$, $\mathrm{Na}$, and $\mathrm{K}$ were $0.1 \%, 17.91 \%, 0.31 \%, 0.14 \%$, and $1.67 \%$, respectively, while those of the 
micro-minerals $\mathrm{Cu}, \mathrm{Zn}$, and Fe were 35.71, 40.60 and $40.72 \mathrm{ppm}$, respectively. Compared with De Blas et al. (2010), the $\mathrm{P}, \mathrm{Ca}, \mathrm{Mg}, \mathrm{Na}, \mathrm{K}, \mathrm{Cu}$, and $\mathrm{Zn}$ contents increased; unlike $\mathrm{Fe}$, that decreased in concentration. Murillo and Suárez (2020) identified the increase in P, Mn, $\mathrm{Fe}, \mathrm{Zn}$, and $\mathrm{Cu}$ of the substrate degraded by Lentinus crinitus and decreased the contents of ash, $\mathrm{Ca}$, and $\mathrm{Mg}$.

The increase observed for $\mathrm{Ca}, \mathrm{Mg}, \mathrm{P}$, and $\mathrm{K}$ in the degraded substrate after 60 days might be due to the addition of mineral supplements commonly applied to Pleurotus spp. to improve yield. One additive is $\mathrm{CaCO}_{3}$, which is applied to control $\mathrm{pH}$, maintain moisture, prevent compaction of the substrate, and foster development of hyphae and fructiferous bodies (Pineda-Insuasti et al. 2014). Other supplements, including lime, ground limestone, $\mathrm{KH}_{2} \mathrm{PO}_{4}, \mathrm{MgSO}_{4} .7 \mathrm{H}_{2} \mathrm{O}$, and $\mathrm{Ca}\left(\mathrm{NO}_{3}\right)_{2} .4 \mathrm{H}_{2} \mathrm{O}$ that all are rich in nitrogen, phosphates, and magnesium are useful for the growing of strains and degrading lignocellulose. In some cases, adding $\mathrm{Cu}$ or $\mathrm{Mn}$ enhances the peroxidase production and thereby optimizes substrate degradation. However, adding mineral supplements is a measure that only considers the economic efficiency of processes, but does not take into account the effects on the degraded substrate for its final application as ruminant feed (Levin et al. 2008; Sharma and Arora 2010).

Akinfemi and Ogunwole (2012) found that rice husk inoculated with P. ostreatus, $P$. pulmonaris, and $P$. tuber-reguim presents a disproportionate Ca:P ratio similar to that which was observed in this study. This imbalance can cause alterations in the ruminants organisms; for example, when the ratio is below optimum (Ca:P ratio of 1:1 to 2:1), dairy cattle tend to suffer hypocalcemia, while male sheep and goats may develop obstructive urolithiasis (urinary stones). In contrast, diets lacking $\mathrm{Ca}$ or $\mathrm{P}$ may result in abnormal bone development, a condition known as rickets in young animals and osteomalacia in adults (NCR 2007). Another mineral that limits the utility of these substrates, as the only food source for sheep is $\mathrm{Cu}$, since concentrations in raw matter above 15 to $20 \mathrm{ppm}$, accompanied by low Mo levels, can cause intoxication and death (Calsamiglia et al. 2009).

In other results, the percentage of $\mathrm{CF}$ decreased significantly $(\mathrm{P} \leq 0.05)$ in all the degraded substrates, compared to controls (Tables 1 and 2). This reduction was because of the use of carbohydrates including cellulose, and the lignin polymer during fungal growth (mass transfer) and metabolism, where they are utilized as an energy source (Shrivastava et al. 2014; Nayan et al. 2018). The ADF, NDF, and HC contents (Tables 1 and 2) decreased with respect to their controls $(\mathrm{P} \leq 0.05)$. A reduction of the ADF and NDF has been reported in fungal-treated substrates (Lynch et al. 2014; Nasehi et al. 2014; Shrivastava et al. 2014; Nasehi et al. 2017) as a consequence degradation of the cell-wall component of the substrates by extra cellular enzymes of fungus (Sánchez 2009; Nasehi et al. 2017).

The use of cell wall fibers by white rot fungi depends on their characteristics as well as on the regulation mechanisms of lignin cellulolytic enzymes, where high concentrations of simple carbohydrates repress the expression of enzymes (Rouches et al. 2016). Therefore, the different species of Pleurotus that are used in the production processes of edible fungi can use the components of the cell wall differently depending on the type of substrate, cultivation time, interaction of the mycelium with the fibers due to the expression of extracellular enzymes, as well as other biotic and abiotic factors.

Adamović et al. (1998) reported reductions of NDF and ADF in wheat straw fermented with P. ostreatus, and a similar tendency for $\mathrm{HC}$ that are similar to those observed in the substrates analyzed herein. Luna et al. (2013) reported the same behavior in barley chaff inoculated with the IE8 strain of $P$. ostreatus. The NDF is related to dry 
matter consumption, ruminal fermentation processes, and the generation and composition of the milk that produced by animals (Calsamiglia et al. 2009) and the ADF content is an indicator of the lignin which is present in plants and lignocellulosic residues, among other materials. Lignin is the main determinant of rumen digestibility. Thus, there is a relation between the amount of lignin present and the feed's digestibility, so that as ADF concentrations increased, the ingestion and digestibility of the dry matter (\%DMD) decreased (Espinoza-Canales et al. 2017; Nayan et al. 2018).

The \%DMD of the substrates degraded by $P$. ostreatus in this study increased from 54 to $57 \%(\mathrm{P} \leq 0.05)$. Although ADF and NDF values decreased in all degraded substrates analyzed in this study, no significant changes in \%DMD were observed in the different companies. This may be due to the percentages of lignin present as well as the fiber content in them. That is why even though company 4 goes from $48.5 \%$ to $42.4 \%$ of ADF, its $\% \mathrm{DMD}$ is $55.9 \%$, which is similar to company 3 and lower than company 1 and 2. Possibly these percentages of ADF and NDF help in fostering the utilization of carbohydrates and their use by microorganisms in the rumen to produce the microbial protein that participates in the formation of energy for product maintenance and synthesis (Rodríguez and Rodríguez 2007). Luna et al. (2013) observed an increase greater than $42 \%$ in the digestibility of the substrate of barley chaff degraded by $P$. ostreatus IE8 after 30 days of cultivation when utilizing the in vitro digestibility technique.

The $\mathrm{CP}$ content differed in all analyzed substrates. Those obtained from companies 1 and 4 increased by of $6.1 \%$ and $6.8 \%$, respectively $(P \leq 0.05)$, unlike the undegraded substrate. These values correspond to those reported with fibrous materials without degrading, for which the CP content is $4.6 \%$ (Urrego et al. 2013). The increase in protein is evident, and this can be attributed to the protein contained in the cereal grains used for the preparation of the primary inoculum used by each company, the fungal biomass generated after the degradation of carbohydrates, exogenous enzymes, stem residues, and fructiferous bodies that remained after harvesting (Wang et al. 2001; Nayan et al. 2018). The increase in soluble protein of all the analyzed substrates was confirmed, as also reported by Nayan et al. (2018).

It seems that $P$. ostreatus decomposed nonprotein nitrogen from substrate lignoprotein and synthesized the released nitrogen into fungal protein (Assi and King 2008). Of the total CP in all the degraded substrates, $60 \%$ represented soluble nitrogen in phosphate borate buffer, in contrast to the undegraded substrate, which measured $43.8 \%$ (Tables 1 and 2).

The protein that is soluble in phosphate-borate is known as a soluble protein, and it is assumed to degrade quickly in the rumen. This fraction is primarily composed primarily of non-protein compounds, such as ammoniacal nitrogen, urea, nitrates, amino-acids, small peptides, and true protein (Mohamed and Chaudhry 2008; Mahesh et al. 2017). Urrego et al. (2013) evaluated the composition of the nitrogenated compound of the residue of a crop of Agaricus bisporus from a Colombian company that used rice husks, sugarcane bagasse, poultry litter, and cotton as culture bed. Those authors observed that $76 \%$ of the total nitrogen content in borate-phosphate buffer consisted of mainly insoluble nitrogen. Regarding the fractions of $\mathrm{CP}$, based on their degradation in the rumen, fraction $\mathrm{A}$ presented an increase compared to controls $(\mathrm{P} \leq 0.05)$. The substrate from company 2 showed the largest change of $9 \%$ to $34 \%$, while the others remained between $28 \%$ and $37 \%$ (Tables 3 and 4). 
Table 1. Nutritional Composition of the Substrates (controls) Used in the Cultivation of $P$. ostreatus by Four Companies in Hidalgo

\begin{tabular}{|c|c|c|c|c|}
\hline Determination & Company 1 & Company 2 & Company 3 & Company 4 \\
\hline Moisture (M) (\%) & $8.6 \pm 0.2$ & $8.1 \pm 0.8$ & $7.6 \pm 0.6$ & $8.9 \pm 0.2$ \\
\hline $\begin{array}{c}\text { Crude protein (CP) } \\
(\%)\end{array}$ & $4.9 \pm 0.2$ & $4.4 \pm 0$ & $4.8 \pm 0$ & $4.4 \pm 0$ \\
\hline Crude fiber (CF) (\%) & $56.5 \pm 0.5$ & $49.6 \pm 0.3$ & $48.4 \pm 0.3$ & $49.5 \pm 0.3$ \\
\hline $\begin{array}{c}\text { Ethereal extract } \\
(\mathrm{EE})(\%)\end{array}$ & $5.7 \pm 0.4$ & $8.3 \pm 0.5$ & $2.7 \pm 0$ & $7.8 \pm 0.9$ \\
\hline Ash (\%) & $7.2 \pm 0.1$ & $10.7 \pm 0.7$ & $11.5 \pm 0.4$ & $14.9 \pm 0.7$ \\
\hline ADF (\%) & $42.2 \pm 0.7$ & $43.1 \pm 0.5$ & $44.9 \pm 0.2$ & $48.5 \pm 0.8$ \\
\hline NDF (\%) & $75.7 \pm 0.1$ & $73.4 \pm 0.9$ & $75.4 \pm 0.3$ & $74.7 \pm 0.1$ \\
\hline HC (\%) & $33.5 \pm 0.6$ & $30.4 \pm 0.4$ & $30.5 \pm 0.1$ & $26.1 \pm 0.7$ \\
\hline DMD (\%) & $56 \pm 0.5$ & $55.4 \pm 0.3$ & $54 \pm 0.1$ & $51.1 \pm 0.6$ \\
\hline Soluble protein & $2.3 \pm 0$ & $1.3 \pm 0$ & $2.3 \pm 0.2$ & $2.2 \pm 0$ \\
\hline Insoluble protein & $2.6 \pm 0$ & $3.1 \pm 0$ & $2.5 \pm 0.2$ & $2.2 \pm 0$ \\
\hline Company
\end{tabular}

Company 1: Substrate of barley chaff/strain P. ostreatus BPR-3 (Tolcayuca); Company 2: Substrate corn chaff - barley straw (50:50)/strain P. ostreatus PR5 (Villas de Tezontepec); Company 3: Substrate corn chaff - oat straw (50:50)/strain P. ostreatus L85 C11 (Progreso de Obregón); Company 4: Substrate corn chaff/strain Pleutorus spp. (Cuautepec de Hinojosa). \pm is for SD.

Table 2. Nutritional Composition of Substrates Degraded by $P$. ostreatus after 60 Days of Cultivation from Four Companies in Hidalgo

\begin{tabular}{|c|c|c|c|c|}
\hline Determination & Company 1 & Company 2 & Company 3 & Company 4 \\
\hline Moisture (M) (\%) & $7.7 \pm 0.7^{\mathrm{a}}$ & $6.8 \pm 0.2^{\mathrm{b}}$ & $6.5 \pm 0.2^{\mathrm{bc}}$ & $6.1 \pm 0.3^{\mathrm{c}}$ \\
\hline Crude protein (CP) (\%) & $6.1 \pm 0.9^{\mathrm{a}}$ & $4.4 \pm 0.3^{\mathrm{b}}$ & $4.9 \pm 0.2^{\mathrm{b}}$ & $6.8 \pm 0.3^{\mathrm{c}}$ \\
\hline Crude fiber (CF) (\%) & $54.1 \pm 0.7^{\mathrm{a}}$ & $45.5 \pm 0.3^{\mathrm{b}}$ & $45.0 \pm 0.5^{\mathrm{b}}$ & $42.7 \pm 2^{\mathrm{c}}$ \\
\hline $\begin{array}{c}\text { Ethereal extract (EE) } \\
(\%)\end{array}$ & $6.2 \pm 0.3^{\mathrm{a}}$ & $8.0 \pm 0.5^{\mathrm{b}}$ & $7.9 \pm 0.9^{\mathrm{b}}$ & $11.0 \pm 0.9^{\mathrm{c}}$ \\
\hline Ash (\%) & $8.3 \pm 0.1^{\mathrm{a}}$ & $20.2 \pm 0.5^{\mathrm{b}}$ & $31.6 \pm 0.7^{\mathrm{c}}$ & $33.1 \pm 0.7^{\mathrm{d}}$ \\
\hline ADF (\%) & $40.8 \pm 0.3^{\mathrm{a}}$ & $39.7 \pm 0.6^{\mathrm{b}}$ & $42.9 \pm 0.4^{\mathrm{c}}$ & $42.4 \pm 0.7^{\mathrm{c}}$ \\
\hline NDF (\%) & $65.8 \pm 2^{\mathrm{a}}$ & $68.0 \pm 0.9^{\mathrm{b}}$ & $58.6 \pm 0.6^{\mathrm{c}}$ & $51.6 \pm 0.5^{\mathrm{d}}$ \\
\hline HC (\%) & $25.1 \pm 2^{\mathrm{a}}$ & $28.3 \pm 0.7^{\mathrm{b}}$ & $16.2 \pm 0.7^{\mathrm{c}}$ & $9.2 \pm 0.8^{\mathrm{d}}$ \\
\hline DMD (\%) & $57.1 \pm 0.2^{\mathrm{a}}$ & $58 \pm 0.4^{\mathrm{b}}$ & $55.5 \pm 0.3^{\mathrm{c}}$ & $55.9 \pm 0.5^{\mathrm{c}}$ \\
\hline Soluble protein & $3.9 \pm 0.1^{\mathrm{a}}$ & $2.6 \pm 0.1^{\mathrm{b}}$ & $2.7 \pm 0.1^{\mathrm{b}}$ & $3.1 \pm 0.2^{\mathrm{c}}$ \\
\hline Insoluble protein & $2.1 \pm 0.1^{\mathrm{a}}$ & $1.8 \pm 0.1^{\mathrm{b}}$ & $2.2 \pm 0.1^{\mathrm{b}}$ & $3.7 \pm 0.2^{\mathrm{c}}$ \\
\hline
\end{tabular}

Company 1: Substrate of barley chaff/strain P. ostreatus BPR-3 (Tolcayuca); Company 2: Substrate corn chaff - barley straw (50:50)/strain P. ostreatus PR5 (Villas de Tezontepec); Company 3: Substrate corn chaff - oat straw (50:50)/strain P. ostreatus L85 C11 (Progreso de Obregón); Company 4: Substrate corn chaff/strain Pleutorus spp. (Cuautepec de Hinojosa). The $a, b, c$, and d between columns indicate significant differences $(P<0.05)$; and \pm is for SD.

This fraction corresponds to the ammoniacal nitrogen, which is available to generate microbial protein (Nayan et al. 2018). Regarding fraction B1 (soluble nitrogen), the substrate from company 1 increased from $18 \%$ to $29 \%$ ( $\mathrm{P} \leq 0.05)$, but fraction $\mathrm{B} 2$ decreased in all substrates (Tables 3 and 4$)(\mathrm{P} \leq 0.05)$. Fraction $\mathrm{B} 3$, the bypass protein, increased significantly in the degraded substrates from companies 2 and 4 . Fraction $\mathrm{C}$, the lignin-linked protein in the degraded substrates from companies 1,2, and 3 showed no significant differences $(\mathrm{P} \leq 0.05)$. WingChing-Jones and Retana (2009) analyzed the nitrogenated lignin-linked compound from transvala hay that is used as a substrate in $P$. 
ostreatus production. They found that $49.3 \%$ of total CP corresponded to fraction C; a higher percentage than the one determined in this study, which averaged $27 \%$. They concluded that transvala hay inoculated with $P$. ostreatus, alone, is not a suitable source of protein for animal feed. Van Soest (2018) suggests that the range of lignin-linked CP in feed should be $3 \%$ to $5 \%$, but due to their physical characteristics, the transvala hay, bales, and chaff inoculated with $P$. ostreatus can keep the ruminal system healthy since they stimulate rumination as long as the amount administered is adequate for the species.

Table 3. Protein Fractions of Various Substrates Used (controls) in the Cultivation of $P$. ostreatus at Four Companies in Hidalgo

\begin{tabular}{|c|c|c|c|c|c|c|c|c|c|c|}
\hline \multirow{2}{*}{ Company } & \multicolumn{10}{|c|}{ Fraction } \\
\cline { 2 - 21 } & $\mathrm{A}$ & $(\%)$ & $\mathrm{B} 1$ & $(\%)$ & $\mathrm{B} 2$ & $(\%)$ & $\mathrm{B} 3$ & $(\%)$ & $\mathrm{C}$ & $\begin{array}{c}(\% \\
)\end{array}$ \\
\hline 1 & $\begin{array}{c}1.5 \pm \\
0\end{array}$ & 30 & $\begin{array}{c}0.9 \pm \\
0\end{array}$ & 18 & $\begin{array}{c}0.9 \pm \\
0\end{array}$ & 18 & $\begin{array}{c}0.3 \pm \\
0\end{array}$ & 7 & $\begin{array}{c}1.3 \pm \\
0.4\end{array}$ & 27 \\
\hline 2 & $\begin{array}{c}0.4 \pm \\
0\end{array}$ & 9 & $\begin{array}{c}0.9 \pm \\
0\end{array}$ & 20 & $\begin{array}{c}1.3 \pm \\
0\end{array}$ & 30 & $\begin{array}{c}0.4 \pm \\
0\end{array}$ & 9 & $\begin{array}{c}1.4 \pm \\
0.4\end{array}$ & 32 \\
\hline 3 & $\begin{array}{c}1.2 \pm \\
0.4\end{array}$ & 25 & $\begin{array}{c}1.1 \pm \\
0.4\end{array}$ & 23 & $\begin{array}{c}0.8 \pm \\
0\end{array}$ & 17 & $\begin{array}{c}0.4 \pm \\
0\end{array}$ & 8 & $\begin{array}{c}1.3 \pm \\
0.4\end{array}$ & 27 \\
\hline 4 & $\begin{array}{c}1.3 \pm \\
0\end{array}$ & 30 & $\begin{array}{c}0.9 \pm \\
0\end{array}$ & 20 & $\begin{array}{c}0.5 \pm \\
0\end{array}$ & 12 & $\begin{array}{c}0.8 \pm \\
0\end{array}$ & 18 & $\begin{array}{c}0.9 \pm \\
0\end{array}$ & 20 \\
\hline
\end{tabular}

Company 1: Substrate of barley chaff/strain P. ostreatus BPR-3 (Tolcayuca); Company 2:

Substrate corn chaff - barley straw (50:50)/strain P. ostreatus PR5 (Villas de Tezontepec); Company 3: Substrate corn chaff - oat straw (50:50)/strain P. ostreatus L85 C11 (Progreso de Obregón); Company 4: Substrate corn chaff/strain Pleutorus spp. (Cuautepec de Hinojosa). The $a, b, c$, and d between columns indicate significant differences $(P<0.05)$; and \pm is for SD; $A$ : Non-protein nitrogen (degraded in the rumen); B1: True soluble protein (degraded in the rumen); B2: True insoluble protein (partially degraded in the rumen and intestine); B3: True insoluble protein in neutral detergent (degraded in the intestine); and C: Insoluble protein in acid detergent (linked to lignin).

Table 4. Protein Fractions of Various Substrates Degraded by P. ostreatus at 60 Days of Cultivation at Four Companies in Hidalgo

\begin{tabular}{|c|c|c|c|c|c|c|c|c|c|c|}
\hline \multirow[b]{2}{*}{ Company } & \multicolumn{10}{|c|}{ Fraction } \\
\hline & $A$ & (\%) & B1 & $(\%)$ & B2 & (\%) & B3 & (\%) & C & (\%) \\
\hline 1 & $\begin{array}{c}2.2 \pm \\
0.1^{\mathrm{a}}\end{array}$ & 36 & $\begin{array}{l}1.8 \pm \\
0.2^{\mathrm{a}}\end{array}$ & 29 & $\begin{array}{c}0.4 \pm \\
0^{\mathrm{a}}\end{array}$ & 7 & $\begin{array}{c}0.3 \pm \\
0^{a}\end{array}$ & 5 & $\begin{array}{l}1.4 \pm \\
0.2^{\mathrm{ab}}\end{array}$ & 23 \\
\hline 2 & $\begin{array}{l}1.5 \pm \\
0.2^{b}\end{array}$ & 34 & $\begin{array}{l}1.0 \pm \\
0.2^{\mathrm{b}}\end{array}$ & 23 & $\begin{array}{c}0.1 \pm \\
0^{\mathrm{b}}\end{array}$ & 2 & $\begin{array}{c}0.5 \pm \\
0^{\mathrm{b}}\end{array}$ & 11 & $\begin{array}{l}1.3^{ \pm} \\
0.4^{\mathrm{b}}\end{array}$ & 30 \\
\hline 3 & $\begin{array}{c}1.8 \pm \\
0^{\mathrm{bc}}\end{array}$ & 37 & $\begin{array}{c}1.0 \pm \\
0^{\mathrm{b}}\end{array}$ & 20 & $\begin{array}{c}0.4 \pm \\
0^{c}\end{array}$ & 8 & $\begin{array}{c}0.3 \pm \\
0^{c}\end{array}$ & 6 & $\begin{array}{l}1.4 \pm \\
0.3^{b}\end{array}$ & 29 \\
\hline 4 & $\begin{array}{l}1.9 \pm \\
0.3^{c}\end{array}$ & 28 & $\begin{array}{l}1.1 \pm \\
0.3^{\mathrm{b}}\end{array}$ & 16 & $\begin{array}{c}0.3 \pm \\
0^{\mathrm{d}}\end{array}$ & 4 & $\begin{array}{c}1.7 \pm \\
0^{c}\end{array}$ & 25 & $\begin{array}{l}1.8 \pm \\
0.1^{\mathrm{a}}\end{array}$ & 2 \\
\hline
\end{tabular}

Company 1: Substrate of barley chaff/strain P. ostreatus BPR-3 (Tolcayuca); Company 2: Substrate corn chaff - barley straw (50:50)/strain $P$. ostreatus PR5 (Villas de Tezontepec); Company 3: Substrate corn chaff - oat straw (50:50)/strain $P$. ostreatus L85 C11 (Progreso de Obregón); Company 4: Substrate corn chaff/strain Pleutorus spp. (Cuautepec de Hinojosa). The $a, b, c$, and d between columns indicate significant differences $(P<0.05)$; and \pm is for SD.; $A$ : Non-protein nitrogen (degraded in the rumen); B1: True soluble protein (degraded in the rumen); B2: True insoluble protein (partially degraded in the rumen and intestine); B3: True insoluble protein in neutral detergent (degraded in the intestine); C: Insoluble protein in acid detergent (linked to lignin); the a, b, $c$ and $d$ between columns indicate significant differences $(P<0.05)$; and \pm denotes SD. 


\section{CONCLUSIONS}

1. The degraded residues obtained from the cultivation of edible fungi analyzed in this study do show an increase in the content of $\mathrm{CP}$ and \%DMD, as well as a decrease in $\mathrm{CF}, \mathrm{ADF}$ and NDF; however, so that these can be used, it is necessary to standardize a single process by using the same strain, a single type of substrate, as well as reducing the use of sulfate calcium and carbonated calcium.

2. The species of Pleurotus used during the cultivation of edible fungi makes it possible to improve the chemical properties of the final substrate, which will depend on the type of substrate, cultivation time, interaction of the mycelium with the fibers due to the expression of extracellular enzymes, as well as other biotic and abiotic factors.

3. To use the degraded residues of the edible mushroom culture in the ruminant diet, it is necessary to carry out inclusion percentage tests according to the nutritional needs for each species and to be added with other supplements.

4. It is necessary to characterize the variations in the content of each mineral and maximum assimilable value, since they are factors that can cause serious problems in the metabolism of ruminants, in particular sheep, which prevent their full use in their diet, due to the high content of copper and other minerals.

\section{ACKNOWLEDGMENTS}

The authors thank CONACYT for Fellowship No. 605069, granted for the Master's Degree studies of Brianda Susana Velázquez De Lucio.

\section{REFERENCES CITED}

Adamović, M., Grubić, G., Milenković, I., Jovanović, R., Protić, R., Sretenović, L., and Stoićević, L. (1998). "The biodegradation of wheat straw by Pleurotus ostreatus mushrooms and its use in cattle feeding," Anim. Feed Sci. Tech. 71(3-4), 357-362. DOI: $10.1016 / \mathrm{S} 0377-8401(97) 00150-8$

Akinfemi, A., and Ogunwole, O. A. (2012). "Chemical composition and in vitro digestibility of rice straw treated with Pleurotus ostreatus, Pleurotus pulmonarius and Pleurotus tuber-regium," Slovak J. Anim. Sci. 45(1), 14-20.

Anike, F. N., Yusuf, M., and Isikhuemhen, O. S. (2016). "Co-sub-strating of peanut shells with cornstalks enhancesbiodegradation by Pleurotus ostreatus," J. Bioremed. Biodeg. 7(1), 327. DOI: $10.4172 / 2155-6199.1000327$

AOAC (2005). "Official method of analysis," $18^{\text {th }}$ Edition, Association of Officiating Analytical Chemists, Washington, DC.

Assi, J. A., and King, A. J. (2008). "Manganese amendment and Pleurotus ostreatus treatment to convert tomato pomace for inclusion in poultry feed," Poult Sci. 87(9), 1889-1896. DOI: $10.3382 /$ ps.2007-00376

Atila, F. (2017). "Biodegradation of different agro-industrial wastes through the cultivation of Pleurotus ostreatus (Jacq. ex. Fr) Kummer," J. Biol. Environ. Sci. 11 (31), 1-9. 
Bellettini, M. B., Fiorda, F. A., Maieves, H. A., Teixeira, G. L., Ávila S., Hornung P. S., Maccari J., and Ribani R. H. (2019). "Factors affecting mushroom Pleurotus spp," Saudi J. Biol. Sci. 26(4), 633-646. DOI: 10.1016/j.sjbs.2016.12.005

Boga, M., Yurtseven, S., Kilic, U., Aydemir, S., and Polat, T. (2014). "Determination of nutrient contents and in vitro gas production values of some legume forages grown in the Harran plain saline soils," Asian-Australas J. Anim Sci. 27(6) 825-831. DOI: 10.5713/ajas.2013.13718

Calsamiglia, S., Bach, A., De Blas, C., Fernández, C., and García-Rebollar, P. (2009). "Necesidades nutricionales para rumiantes de leche normas FEDNA," (http://vet. unicen. edu. ar/ActividadesCurriculares/ProduccionBovinosCarneLeche/ images/Documentos/Alimentación Rumiantes/Alvarado/Sistema de Alimentacion/ NORMAS_LECHE_2009. pdf), accessed on 20th October 2018.

De Blas, C., Mateos, G. G., and García-Rebollar, P. (2010). Tablas FEDNA de Composición y Valor Nutritivo de Alimentos para la Fabricación de Piensos Compuestos (FEDNA Tables of Composition and Nutritional Value of Food for the Manufacture of Compound Feed), Fundación Española para el Desarrollo de la Nutrición Animal, Madrid.

Espinoza-Canales, A., Gutiérrez-Bañuelos, H., Sánchez-Gutiérrez, R. A., Muro-Reyes, A., Gutiérrez-Piña, F. J., and Corral-Luna, A. (2017). "Calidad de forraje de canola (Brassica napus L.) en floraciones temprana y tardía bajo condiciones de temporal en Zacatecas, México (Quality of canola (Brassica napus L.) forage in early and late blooms under temporary conditions in Zacatecas, Mexico)," Rev. Mex. de Cienc. Pecuarias [online] 8(3), 243-248. DOI: 10.22319/rmcp.v8i3.4501.

Hammer, O. (2018). PAST: Paleontological Statistics Software Package for Education and Data Analysis, Paleontología Electrónica. (https://folk.uio.no/ohammer/past/), accessed 10 October 2018.

Koutrotsios, G., Mountzouris, K. C., Chatzipavlidis, I., and Zervakis, G. I. (2014). "Bioconversion of lignocellulosic residues by Agrocybe cylindracea and Pleurotus ostreatus mushroom fungi - Assessment of their effect on the final product and spent substrate properties," Food Chem. 161, 127-135. DOI:

10.1016/j.foodchem.2014.03.121

Krishnamoorthy, U., Muscato, T. V., Sniffen, C. J., and Van Soest, P. J. (1982). "Nitrogen fractions in selected feedstuffs," J. Dairy Sci. 65(2), 217-225. DOI: 10.3168/jds.S0022-0302(82)82180-2

Lanzas, C., Broderick, G. A., and Fox, D. G. (2008). "Improved feed protein fractionation schemes for formulating rations with the Cornell Net Carbohydrate and Protein System," J. Dairy Sci. 91(12), 4881-4891. DOI: 10.3168/jds.2008-1440

Levin, L., Herrmann, C., and Papinutti, V. L. (2008). “Optimization of lignocellulolytic enzyme production by the white-rot fungus Trametes trogii in solid-state fermentation using response surface methodology," Biochem. Eng. J. 39(1), 207-214. DOI: 10.1016/j.bej.2007.09.004

Linn, J. G., and Martin, N. P. (1991). "Forage quality analyses and interpretation," Vet. Clin. North Am. Small Anim. Pract. 7(2), 509-523. DOI: 10.1016/S07490720(15)30790-8

Luna, L., Meneses, M., Mendoza, G., Montalvo, C., Loera, O., Losada, H., Vargas, J., and Cortés, J. (2013). "Effect and enzyme activity of Pleurotus ostreatus on cell wall of barley straw," Livest. Res. Rural. Dev. 25. 
Lynch, J. P., O'Kiely, P., Murphy, R., and Doyle, M. (2014). "Changes in chemical composition and digestibility of three maize stover components digested by white-rot fungi," J. Anim. Physiol. Anim. Nutr. (Berl). 98(4), 731-738. DOI: 10.1111/jpn.12131

Mahesh, M. S., Thakur, S. S., Kumar, R., Malik, T. A., and Gami, R. (2017). "Nitrogen fractionation of certain conventional-and lesser-known by-products for ruminants," Anim Nutr. 3(2) 186-190. DOI: 10.1016/j.aninu.2017.04.003

Martínez-Carrera, D., Larqué-Saavedra, A., Tovar, P. A., Torres, N., Meneses, M. E., Sobal, C. M., Morales, A. P., Bonilla, Q. M., Escudero, U. H., Tello-Salgado, I., Bernabé, G. T., Martínez, S. W., and Mayett, Y. (2016). “Contribución de los hongos comestibles funcionales y medicinales a la construcción de un paradigma sobre la producción, la dieta, la salud y la cultura en el sistema agroalimentario de México" in: Ciencia, Tecnología e Innovación en el Sistema Agroalimentario de México (Contribution of functional and medicinal edible mushrooms to the construction of a paradigm on production, diet, health and culture in the Mexican food system "in: Science, Technology and Innovation in the Mexican Food System), D. MartínezCarrera and J. Ramírez (ed.), Ed del Colegio de Postgraduados-AMC-CONACYTUPAEP-IMINAP, pp. 581-640.

Mohamed, R., and Chaudhry, A. S. (2008). "Methods to study degradation of ruminant feeds," Nutr. Res. Rev. 21(1), 68-81. DOI: 10.1017/s0954422408960674

Murillo, W., and Suárez, H. (2020). "Evaluation of nutritional values of wild mushrooms and spent substrate of Lentinus crinitus (L.) Fr," Heliyon 6(3), e03502. DOI: 10.1016/j.heliyon.2020.e03502

Nasehi, M., Torbatinejad, N. M., Zerehdaran, S., and Safaei, A. R. (2014). "Effect of (Pleurotus florida) fungi on chemical composition and rumen degradability of wheat and barley straw," Iran. J. Appl. Anim. Sci. 4(2), 257-261.

Nasehi, M., Torbatinejad, N. M., Zerehdaran, S., and Safaie, A. R. (2017). "Effect of solid-state fermentation by oyster mushroom (Pleurotus florida) on nutritive value of some agro by-products," J. Appl. Anim. Res. 45(1), 221-226. DOI: 10.1080/09712119.2016.1150850

National Research Council (NCR). (2007). Nutrient Requirements of Small Ruminants: Sheep, Goats, Cervids, and New World Camelids, The National Academies Press, Washington, DC. DOI: 10.17226/11654.

Nayan, N., Sonnenberg, A. S., Hendriks, W. H., and Cone, J. W. (2018) "Variation in the solubilization of crude protein in wheat straw by different white-rot fungi," Anim. Feed Sci. Technol. 242, 135-143. DOI: 10.1016/j.anifeedsci.2018.06.009

Pineda-Insuasti, J. A., Ramos-Sánchez, L. B., and Soto-Arroyave, C. P. (2014). "Producción de Pleurotus ostreatus por fermentación en estado sólido: Una revisión," ICIDCA. Sobre los Derivados de la Caña de Azúcar 48(2), 13-22. (http://www.redalyc.org/articulo.oa?id=223131465002), accessed on $20^{\text {th }}$ November 2018

Rodríguez, R., Sosa, A., and Rodríguez, Y. (2007). "Microbial protein synthesis in rumen and its importance to ruminants," Cuban J. Agr. Sci. 41(4) 287-294.

Romero-Arenas, O., Martínez, G. M. A., Damián, H. M. A., Ramírez, B., and LópezOlguín, J. F. (2015). "Producción del hongo Shiitake (Lentinula edodes Pegler) en bloques sintéticos utilizando residuos agroforestales," Rev. Mex. Cienc. Agríc. 6(6), 1229-1238. (http://www.scielo.org.mx/scielo.php?script=sci_arttext\&pid=S200709342015000600007\&lng=es\&tlng=es) accessed on 19 th 2020. 
Royse, D. J., Baars, J., and Tan, Q. (2017). "Current overview of mushroom production in the world Cap 2," in: Edible and Medicinal Mushrooms, C. Z. Diego, A. PardoGiménez (ed.), Wiley, Hoboken, NJ, USA. DOI: 10.1002/9781119149446.ch2

Ruiloba, M. H., Vega, A., Franco, H., Solís, C., and García, C. R. (2014). "Efecto de la bio-degradación con cepas nativas de Pleurotus djamor, RN81 y RN82, sobre parámetros químicos y degradabilidad in situ de sustratos lignocelulósicos," Revista Científica 24(5), 43-453.

Sánchez, C. (2009). "Lignocellulosic residues: Biodegradation and bioconversion by fungi," Biotechnol. Adv. 27(2), 185-194. DOI: 10.1016/j.biotechadv.2008.11.001

Sharma, R. K., and Arora, D. S. (2010). "Production of lignocellulolytic enzymes and enhancement of in vitro digestibility during solid state fermentation of wheat straw by Phlebia floridensis," Bioresource Technol. 101(23), 9248-9253, DOI: 10.1016/j.biortech.2010.07.042

Shrivastava, B., Jain, K. K., Kalra, A., and Kuhad, R. C. (2014). "Bioprocessing of wheat straw into nutritionally rich and digested cattle feed," Sci. Rep. 4(1), 6360. DOI: 10.1038/srep06360

Sniffen, C. J. J., O’Connor, D. O., Vansoest, P. J., Fox, D. G., and Russell, J. B. (1992). "A net carbohydrate and protein system for evaluating cattle diets: II. Carbohydrate and protein availability," J. Anim. Sci. 70 (11), 3562-3577. DOI: 10.2527/1992.70113562x

Spears, J. W., and Weiss, W. P. (2014). "Invited review: Mineral and vitamin nutrition in ruminants,” PAS 30(2), 180-191. DOI: 10.15232/S1080-7446(15)30103-0

Tripathi, J. P., and Yadav, J. S. (1992). "Optimization of solid substrate fermentation of wheat straw into animal feed by Pleurotus ostreatus: A pilot effort," Anim. Feed Sci. Tech. 37(1-2), 59-72. DOI: 10.1016/0377-8401(92)90120-U

Urrego, J. M. G., Jaramillo, S. A. Y., and Rosales, R. B. (2013). "Nutritional characterization of the crop residue of mushroom Agaricus bisporus as a potential feed for cattle," Ces. Med. Vet. Zootec. 8(1), 34-56. (http://www.redalyc.org/ articulo.oa?id=321428109004), accessed on $7^{\text {th }}$ July 2018.

Van Kuijk, S. J. A., Sonnenberg, A. S. M., Baars, J. J. P., Hendriks, W. H., and Cone, J. W. (2015). "Fungal treated lignocellulosic biomass as ruminant feed ingredient: A review," Biotechnol Adv. 33(1), 191-202. DOI: 10.1016/j.biotechadv.2014.10.014

Van Soest, P. J. (2018). Nutritional Ecology of the Ruminan, Cornell University press, DOI: $10.7591 / 9781501732355$

Van Soest, P. J., Robertson, J. B., and Lewis, B. A. (1991). "Methods for dietary fiber, neutral detergent fiber, and nonstarch polysaccharides in relation to animal nutrition," J. Dairy Sci. 74(10), 3583-3597. DOI: 10.3168/jds.S0022-0302(91)78551-2

Villas-Bôas, S. G., Esposito, E., and Mitchell, D. A. (2002). "Microbial conversion of lignocellulosic residues for production of animal feeds," Anim. Feed. Sci. Technol. 98(1-2), 1-12. DOI: 10.1016/S0377-8401(02)00017-2

Wang, D., Sakoda, A., and Suzuki, M. (2001). "Biological efficiency and nutritional value of Pleurotus ostreatus cultivated on spent beer grain," Bioresource Technol. 78(1), 293-300. DOI: 10.1016/s0960-8524(01)00002-5

Wanzenböck, E., Apprich, S., Tirpanalan, Ö., Zitz, U., Kracher, D., Schedle, K., and Kneifel, W. (2017). "Wheat bran biodegradation by edible Pleurotus fungi - A sustainable perspective for food and feed," LWT-Food Sci. Technol. 86(1), 123-131. DOI: 10.1016/j.lwt.2017.07.051 
Wing Ching-Jones, R., and Retana, G. A. (2009). "Valor nutricional del heno de transvala inoculado con el hongo Pleurotus ostreatus sp," Agron. Costarric. 33(1), 147-153.

Zhang, R., Li, X., and Fadel, J. G. (2014). "Oyster mushroom cultivation with rice and wheat straw," Bioresource Technol. 82(3), 277-284. DOI: 10.1016/S09608524(01)00188-2

Article submitted: July 6, 2020; Peer review completed: August 23, 2020; Revised version received and accepted: September 25, 2020; Published: October 9, 2020.

DOI: $10.15376 /$ biores.15.4.8849-8861 